\section{Cold Injury of Southern Blueberries as a Function of Germplasm and Season of Flower Bud Development}

\author{
Kim Patten', Elizabeth Neuendorff, and Gary Nimr ${ }^{3}$ \\ Texas Agricultural Experiment Station, Overton, TX 75684
}

\author{
John R. Clark ${ }^{4}$ and Gina Fernandez ${ }^{5}$ \\ University of Arkansas Fruit Substation, Route 3, Clarksville, AR 72830
}

Additional index words. rabbiteye blueberry, southern highbush, low-chill highbush, Vaccinium ashei, frost tolerance, freeze damage

\begin{abstract}
The relative tolerance of flower buds and flowers of southern highbush blueberry (Vaccinium spp.) to cold damage was compared to rabbiteye (Vaccinium ashei Reade) and highbush blueberry (Vaccinium corymbosum L.). For similar stages of floral bud development, southern highbush and highbush cultivars had less winter freeze and spring frost damage than rabbiteye cultivars. Cold damage increased linearly with stage of flower bud development. Small fruit were more sensitive to frost damage than open flowers. Rabbiteye blueberry flower buds formed during the fall growth flush were more hardy than buds formed during the spring growth flush, regardless of cultivar or stage of development.
\end{abstract}

Rabbiteye blueberry production in the southern United States is routinely plagued by intermittent temperature extremes during the winter and early spring. After sufficient chilling units have been received, unseasonably warm temperatures may cause loss of winter hardiness (Eck, 1988) and/or accelerated floral bud development (Spiers and Draper, 1974). Cold injury to floral tissue frequently occurs when these warm episodes are followed by subfreezing temperatures. Research on the variability in tolerance of blueberry germplasm to cold injury indicated that it is largely a function of floral bud development (Clark et al., 1986; Gupton, 1983; Hancock et al., 1987; Spiers, 1978, 1981). Blueberry germplasm, such as the southern highbush, with low-chilling requirements and more rapid bud development in the spring may be especially sensitive to this type of cold damage. The southern highbush blueberry is a hybrid of northern highbush and Vaccinium darrowi Camp. It has the early fruit maturity of northern highbush and low chilling of $V$. darrowi (Eck, 1988). We found no studies comparing the relative cold hardiness of southern highbush flower buds to midwinter freezes and spring frost to rabbiteye or highbush blueberry.

For blueberries, time of anthesis is partly

Received for publication 26 Feb. 1990. Texas Agricultural Experiment Station Publication no. TA 25302. The cost of publishing this paper was defrayed in part by tire payment of page charges. Underpostal regulations, this paper therefore must be hereby marked advertisement solely to indicate this fact.

'AssistantProfessor.Current address: Washington State Univ.-Longbeach Res. \& Ext. Unit, Route 1, Box 570, Longbeach, WA 98631.

${ }^{2}$ Research Associate.

${ }^{3}$ Research Technician

${ }^{4}$ Resident Director.

${ }^{5}$ Research Specialist. and location.

${ }^{\mathrm{z}}$ Analysis done on stage 2 flower buds. assessed at Clarksville, Ark.
'Brightwell', and 'Baldwin'), and highbush ('Croatan') blueberry cultivars was evaluated following winter freeze. The plants compared in these studies were from the 1984 southern regional germplasm evaluation plantings at Overton, Texas, and Clarksville, Ark. (32 and $35.5^{\circ}$ latitude, respectively). In Feb. 1989, a severe winter freeze followed 2 weeks of warm weather. Mean minimum and maximum temperatures from $25 \mathrm{Jan}$. to 3 Feb. were 8 and $21 \mathrm{C}$ for Overton, and 2 and $15 \mathrm{C}$ for Clarksville, respectively. On 4 Feb., the temperature in Overton fell to - 10C and remained below $-6 \mathrm{C}$ for 5 days, and at Clarksville the temperature fell to $-13 \mathrm{C}$ and remained below $-11 \mathrm{C}$ for 6 days. Shoots were collected on 13 Feb. from four wholeplant replications for each cultivar. About 20 flower buds from three to five shoots per plant were cut transversely and examined for dead ovaries under a $10 \times$ binocular scope. For each bud examined, the number of ovaries that exhibited oxidative browning, total number of ovaries, bud diameter, stage of floral development (Spiers, 1978), and numerical location of the bud in a basipetal direction were recorded. Stem damage was subjectively rated $(1=$ no browning, $3=$ slight browning, $5=$ total browning) for flower buds at Clarksville. Percent fruit set was evaluated in May at both locations. Set was counted on 30 flowers per plant for four plants for each cultivar. The experimental design was a split plot (location = whole plots, cultivars $=$ subplots), with replications nested within location. Analysis of percentage values was performed after arcsin transformation. Analysis of ovary damage across both locations was done only on buds at stage 2 (visible swelling, scales separating, flowers still completely enclosed). For each location and cultivar, percent damage was correlated with bud stage, bud thickness, and bud position. Analysis of variance (ANOVA) of fruit set was performed separately for each location. Orthogonal con-

Table 1. Cold injury to flower buds and stems of southern blueberries as a function of germplasm

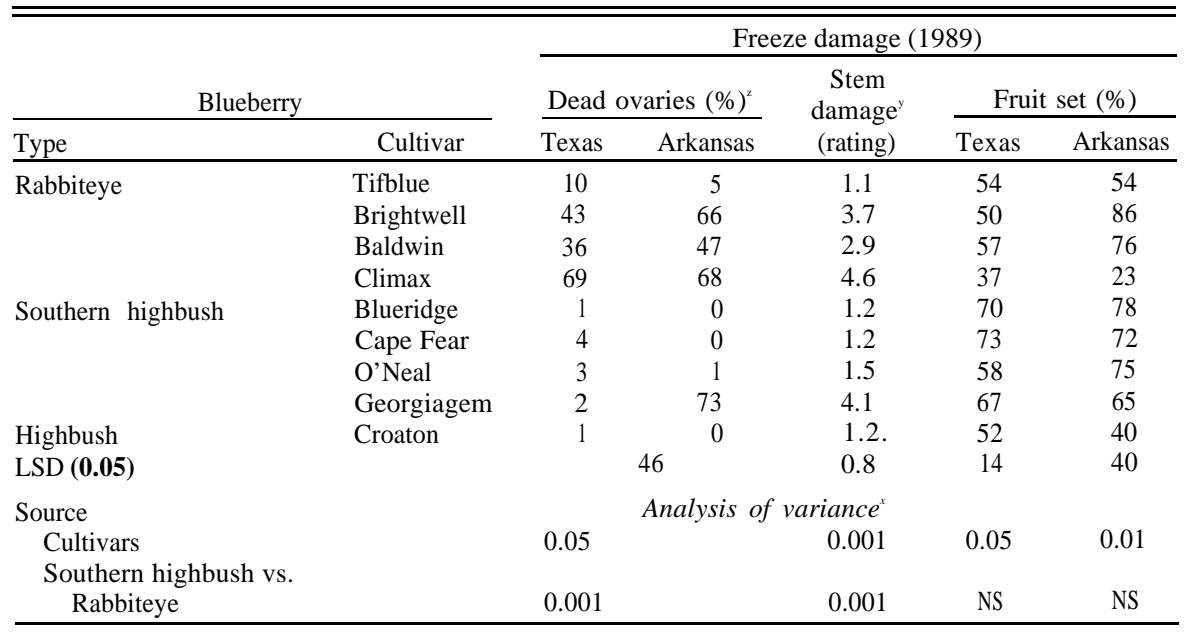

${ }^{\text {y }}$ Stem damage rating, 1 = no damage, 3 = slight damage, 5 = dead plant, stems dark brown; damage

${ }^{x}$ Probability of significant F value, NS = nonsignificant. 
Table 2. Cold injury to flower and fruit of southern blueberries as a function of germplasm and stage of development.

\begin{tabular}{|c|c|c|c|c|c|c|c|}
\hline & & \multicolumn{6}{|c|}{ Frost damage (\% dead ovaries $)^{2}$} \\
\hline & & & 1988 & & & 1989 & \\
\hline \multicolumn{2}{|c|}{ Blueberry } & \multicolumn{6}{|c|}{ Flower stage of development } \\
\hline Type & Cultivar & $4^{y}$ & $5^{y}$ & $6^{y}$ & $6^{x}$ & $6^{w}$ & $>7^{\mathrm{w}}$ \\
\hline \multirow[t]{4}{*}{ Rabbiteye } & Tifblue & 10 & 74 & $\ldots{ }^{\mathrm{v}}$ & 5 & 53 & 89 \\
\hline & Brightwell & 0 & 38 & 100 & 11 & 24 & 95 \\
\hline & Baldwin & & 48 & --- & 19 & 21 & 83 \\
\hline & Climax & 30 & 73 & 100 & 36 & 49 & 99 \\
\hline \multirow[t]{4}{*}{ Southern highbush } & Blueridge & 0 & 26 & 63 & 1 & 14 & 100 \\
\hline & Cape Fear & 0 & 22 & 79 & 0 & 11 & 95 \\
\hline & O’Neal & 20 & 18 & 83 & 3 & 14 & 98 \\
\hline & Georgiagem & 0 & 13 & 53 & 0 & 10 & 94 \\
\hline \multirow{2}{*}{\multicolumn{2}{|c|}{$\begin{array}{l}\text { Highbush } \\
\text { LSD }(0.05)\end{array}$}} & $\ldots$ &.,.. &..- & 0 & 7 & 76 \\
\hline & & 22 & 22 & 22 & 12 & 7 & 10 \\
\hline \multirow{2}{*}{\multicolumn{2}{|c|}{ Source }} & \multicolumn{5}{|c|}{ Analysis of variance } & \\
\hline & & 0.01 & 0.01 & 0.01 & 0.01 & 0.01 & 0.01 \\
\hline \multicolumn{2}{|c|}{ Southern Highbush vs. } & & & & & & \\
\hline \multicolumn{2}{|c|}{ Rabbiteye } & 0.01 & 0.001 & 0.01 & 0.01 & 0.001 & NS \\
\hline 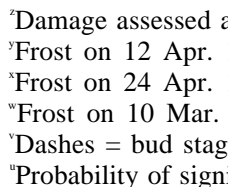 & $\begin{array}{l}\text { Texas. } \\
\text { C. } \\
\text { C. } \\
\text { C. } \\
\text { ble or data } 1 \\
\text { ue, NS = no }\end{array}$ & & & & & & \\
\hline
\end{tabular}

Table 3. Cold injury damage of rabbiteye blueberries as a function of cultivar and season of wood growth.

\begin{tabular}{|c|c|c|c|c|}
\hline \multirow[b]{2}{*}{ Cultivar } & \multirow[b]{2}{*}{$\begin{array}{c}\text { Season of } \\
\text { wood growth }\end{array}$} & \multirow[b]{2}{*}{$\frac{\text { Freeze damage on } 3 \text { Feb. }}{\text { Dead ovaries }(\%)}$} & \multicolumn{2}{|c|}{ Frost damage on 27 Mar. } \\
\hline & & & $\begin{array}{c}\text { Dead ovaries } \\
(\%)\end{array}$ & $\begin{array}{l}\text { Stem damage }^{2} \\
\text { (rating) }\end{array}$ \\
\hline \multirow[t]{2}{*}{ Tifblue } & Spring & 50 & 5 & 1.25 \\
\hline & Fall & 28 & 0 & 1.0 \\
\hline \multirow[t]{3}{*}{ Delite } & Spring & 99 & 100 & 3.0 \\
\hline & Fall & 89 & 91 & 1.9 \\
\hline & & \multicolumn{3}{|c|}{ Analysis of variance ${ }^{y}$} \\
\hline \multicolumn{5}{|l|}{ Source } \\
\hline Cultivar & & 0.05 & 0.001 & 0.05 \\
\hline Season & & 0.05 & 0.001 & 0.01 \\
\hline Interaction & & NS & 0.001 & $\mathrm{NS}$ \\
\hline
\end{tabular}

${ }^{2} 1$ = no damage, 5 = dead plant.

${ }^{\mathrm{y}}$ Probability of significant $\mathrm{F}$ value, NS = nonsignificant.

trasts were used to compare differences in cold injury between rabbiteye and southern highbush blueberries.

A further evaluation of germplasm variability to cold damage was done at-an experimental planting in Nacogdoches, Texas ( $31.5^{\circ}$ latitude). The percentage of dead ovaries was evaluated--on shoots collected after the Feb. 1989 freeze (minimum = -8C). Twenty buds per plant for four whole-plant replications were examined for rabbiteye cultivars Beckyblue, Bonita, and Climax, and for southern highbush cultivars Gulf Coast and Cooper. ANOVA of percent dead ovaries was performed after arcsin transformation using orthogonal contrast to compare rabbiteye and southern highbush blueberries.

To evaluate cold tolerance across a wide range of bud development, shoots containing flower buds ranging from stage 2 to 5 were selectively collected on 12 Feb. 1989 at Overton for 'Climax', 'O'Neal', and 'Georgiagem'. The percentage of injured ovaries was determined on two shoots per plant $(\approx 15$ buds) with five whole-plant replications per cultivar. Relationship between percentage of injured ovaries and stage of bud development was determined by linear regression.
In general, southern highbush blueberry had less freeze damage than rabbiteye at both locations (Table 1). Cold tolerance varied within each type of blueberry, and there was a location $x$ cultivar interaction. For rabbiteye, regardless of location, 'Climax' had the most winter freeze damage to bud and stem tissue and 'Tifblue' the least. In Arkansas, 'Georgiagem' had the highest level of freeze damage to buds and stems of all blueberry cultivars, whereas in Texas damage levels for 'Georgiagem' were similar to other southern highbush cultivars. The single highbush cultivar represented in this study, 'Croatan', had levels of cold injury similar to southern highbush. Fruit set data in 1989 were confounded by subsequent frost damage to previously undamaged flower buds. The only consistent trend observed between both locations is that 'Climax' had the lowest percent fruit set among rabbiteye cultivars and that 'Croatan' had lower set than southern highbush cultivars. Regression analysis was performed within each location and cultivar to determine the relationship between location of the bud, or bud diameter to percent dead ovaries. No significant linear relationship was found.
In the Nacogdoches test, there was no difference in hardiness within types of blueberry, but southern highbush had less damage than rabbiteye (10\% vs. $34 \%$ dead ovaries; $P>0.5$ ).

Based on the February freeze, damage to floral tissue of southern highbush blueberry was linearly related to stage of bud development (Fig. 1). For 'Climax', all buds more advanced than stage 3 were killed.

Germplasm effects on flower and fruit hardiness. In 1988 and 1989 at Overton, frost damage was evaluated three times as a function of stage of flower/fruit development. Plants were evaluated 2 days after minima of -4 and $-2 \mathrm{C}$ on 12 and 24 Apr. 1988 and $-2 \mathrm{C}$ on 10 Mar. 1989. On 14 Apr. 1988 , flowers were evaluated at three stages of development $(4=$ individual flower distinguishable, bud scales abscised; $5=$ individual flowers distinctly separated, corollas unexpanded and closed; $6=$ corollas completely open) (Spiers, 1978) for ovaries exhibiting oxidative browning. There were 30 flowers per stage per replication on three whole-plant replications. On 26 Apr. 1988, 100 previously undamaged flowers at stage 6 were evaluated per plant, on four wholeplant replications for each cultivar. On 12 Mar. 1989,50 flowers at stage 6 and 50 fruit (post-petal fall) were evaluated per plant on four whole-plant replications for each cultivar. ANOVA was performed within each stage of development and time of damage. Orthogonal contrast was used to compare differences in frost damage between rabbiteye and southern highbush cultivars.

Southern highbush blueberry had less frost damage than rabbiteye at similar stages of flower bud development for both years (Table 2). Frost tolerance varied within each type of blueberry. For rabbiteye blueberries, 'Climax' usually had the most damage to flowers, regardless of stage of development. Rankings of damage levels among the other 


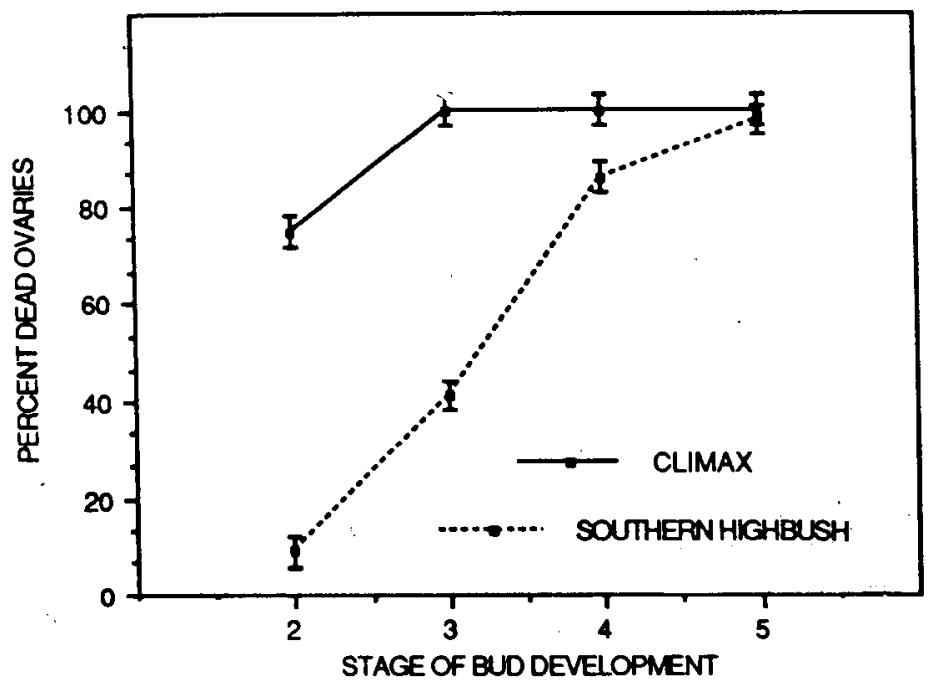

Fig. 1. Percentage of dead ovaries at various stages of bud development $(2=$ visible swelling, $3=$ bud scales separated, $4=$ individual flower distinguishable, $5=$ individual flower distinctly separated) for 'Climax' and southern highbush (pooled data for 'O'Neal' and 'Georgiagem') blueberry. $($ Bars $=\mathrm{SE})$.

three rabbiteye cultivars were inconsistent. Among rabbiteye and southern highbush, 'Baldwin' had the least amount of damage to fruit (Stage 7). Fruit tissue for all cultivars was more sensitive to cold than floral tissue. Open flowers of 'Georgiagem' were less damaged than those of other southern highbush on 12 Apr. 1988. This result likely was an anomaly, since at all other times and bloom stages 'Georgiagem' had levels of frost damage similar to that of other southern highbush cultivars. 'Croatan' highbush was more tolerant of frost damage to flowers than rabbiteye germplasm and slightly more tolerant of frost damage to fruit than southern highbush germplasm.

It is evident from the first two studies that southern highbush floral tissue is more hardy than rabbiteye blueberry floral tissue. Any tendency for early bud development on the low-chill germplasm to enhance the potential for cold damage appears to be moderated by the apparent greater tolerance of this germplasm to cold.

Season of flower bud development. Shoots on 6-year-old 'Tifblue' and 'Delite' blueberry plants were delineated in Fall 1988 by their season. of growth (spring vs. late summer/fall). Following the freeze on 3 Feb. 1989, fruiting shoots from each cultivar and growth flush were collected on 9 Feb. Thirty flower buds from five shoots per plant for each growth flush were cut transversely and examined for oxidative browning. There were six whole-plant replications per cultivar. Flower buds that survived the February freeze were further evaluated on 27 Mar. at stage 6 , for their resistance to $-2 \mathrm{C}$ frost on 23 Mar. Fifty flowers were examined per replication for each growth flush period. There were four replications per cultivar. Cold damage to spring and fall shoots following the March frost was also rated $(1=$ no damage, $3=25 \%$ dead shoot tips, $5=$ dead plant) on 27 Mar. There were four wholeplant replications per cultivar. ANOVA on the percentage of dead ovaries was performed after arcsin transformation.

'Delite' reproductive and stem tissue was much less tolerant to cold damage than 'Tifblue' (Table 3). This result closely agrees with previous data (Clark et al., 1986; Spiers, 1981). Flower buds and stem tissue formed on fall growth flushes had less cold damage than those formed on spring growth. The difference in degree of cold injury between 'Delite' on fall wood and on spring wood, although significant, was not enough to provide for an adequate crop. There was no difference in fruit set for flowers from different growth flushes (data not shown).

Our data from previous years (not shown) indicated that anthesis for flower buds formed on fall wood usually was much later (1 to 4 weeks) than buds formed on spring wood. The decrease in cold damage to buds on fall wood may be associated with this delay in flower bud development. In spite of the attempt to evaluate buds of similar diameter and stage of development in this study, indiscernible differences in bud ontogeny during sampling may have accounted for some of the hardiness differences.

Based on these data, it may be a feasible production practice to encourage the production of fall wood by summer-pruning after harvest. The flower buds formed on the resulting growth flushes could afford a possible means to avoid frost damage. Fruit quality has not appeared to be significantly affected by this practice (data not shown). This production practice, however, is feasible only when plant vigor and growing season are sufficient to achieve adequate late summer/ fall growth before the cessation of growth in the late fall.

\section{Literature Cited}

Clark, J. R., J.N. Moore, and E.C. Baker. 1986 Cold damage to flower buds of rabbiteye blueberry cultivars. Ark Farm Res. 35(6):3.

Davies, F.S. 1986. Flower position, growth regulators, and fruit set of rabbiteye blueberries. J. Amer. Soc. Hort. Sci. 111:338-341.

Eck, P. 1988. Blueberry culture. Rutgers Univ. Press, New Brunswick, N.J.

Gupton, C.L. 1983. Variability among rabbiteye blueberry cultivars for tolerance of flowers to frost. HortScience 18:713-714.

Hancock, J. F., J.W. Nelson, H.C. Bittenbender, P.W. Callow, J.S. Cameron, S.L. Kerbs, M.P. Pritts, and C.M. Schumann. 1987. Variation among highbush blueberry cultivars in susceptibility to spring frost. J. Amer. Soc. Hort. Sci. 112:702-706.

Mainland, C.M. 1989. Managing the growth and fruiting of rabbiteye (Vaccinium ashei Reade) blueberries with pruning and growth regulators. Acts Hort. 241:195-200.

Spiers, J.M. 1978. Effect of stage of bud development on cold injury in rabbiteye blueberry. J. Amer. Soc. Hort. Sci. 103:452-455.

Spiers, J.M. 1981. Freeze damage in six rabbiteye blueberry cultivars. Fruit Var. J. 35:68-70.

Spiers, J.M. and A.D. Draper. 1974. Effect of chilling on bud break in rabbiteye blueberry. J. Amer. Soc. Hort. Sci. 99:398-399. 